\title{
Failure of Heavy Chain Glycosylation of IgG in Some Patients with Common, Variable Agammaglobulinemia
}

\author{
Filippo Ciccimarra, Fred S. Rosen, Eveline Schneeberger, and \\ Ezio MerLer \\ From the Immunology Division of the Department of Medicine and the \\ Department of Pathology, Children's Hospital Medical Center, and the \\ Departments of Pediatrics and Pathology, Harvard Medical School, \\ Boston, Massachusetts 02115
}

\begin{abstract}
A B S T R A C T Four patients with common, variable agammaglobulinemia were previously reported to have normal numbers of circulating $B$ lymphocytes which synthesized normal amounts of $\mathrm{IgG}$ in tissue culture but failed to secrete the newly synthesized IgG. The B lymphocytes of these patients fail to incorporate $\left[{ }^{3} \mathrm{H}\right] \mathrm{man}-$ nose and/or $\left[{ }^{3} \mathrm{H}\right]$ glucosamine into newly synthesized IgG, whereas such incorporation appears to occur just before IgG secretion in cultures of normal B lymphocytes.
\end{abstract}

\section{INTRODUCTION}

B lymphocytes mature into antibody-synthesizing and -secreting cells. They can be induced, in vitro, to change into antibody-producing cells by antigen together with a factor derived from sensitized $T$ cells, lymphocyte mitogenic factor (LMF).' Under such circumstances, B lymphocytes enlarge, form new DNA, divide, develop abundant rough endoplasmic reticulum, and synthesize and secrete antibody (1).

Most boys with X-linked agammaglobulinemia $(2,3)$ and some adults with the common, variable form of

Dr. Ciccimarra's present address is Department of Pediatrics, 2nd Faculty of Medicine, Università di Napoli, Naples, Italy.

Received for publication 6 November 1975 and in revised form 6 February 1976.

1 Abbreviation used in this paper: LMF, lymphocyte mitogenic factor. agammaglobulinemia lack B lymphocytes from peripheral blood $(4,5)$, lymph nodes, spleen, and bone marrow, sites where B lymphocytes are commonly found. Most patients with common, variable or "acquired" agammaglobulinemia have normal or increased numbers of circulating B lymphocytes $(5,6)$. We previously reported (4) that 15 such patients either had B lymphocytes which were unresponsive to LMF and antigen (nine cases) or had B lymphocytes which responded normally by synthesizing gamma globulin but failed to secrete it (five cases) or had normal B cells when removed from a serum inhibitor present in the patient's blood (one case).

The present study concerns the B lymphocytes of four of the five patients whose cells had a secretory bloc. The fifth patient in this group was unavailable for study. It was of interest to study the glycosylation of newly synthesized gamma globulin in the $B$ cells of the four patients with the secretory bloc. Glycosylation of gamma globulin normally occurs just before its secretion $(7,8)$. In the $B$ lymphocytes of the four patients with the secretory bloc, it was found that no sugar was incorporated into newly synthesized gamma globulin.

\section{METHODS}

The four patients with agammaglobulinemia who donated their blood for the present study were identified in a previous report (4) as case numbers 13-3, 23-30, 23-13, and 18-12. The objectives of the study were explained to 
the patients or their parents, and informed consent was obtained.

B lymphocytes were obtained from the peripheral blood of the aforementioned agammaglobulinemic patients or normal donors, drawn into heparin, and subsequently admixed with $6 \%$ dextran in saline $(5: 1$ volumes of heparinized blood: dextran). Leukocyte-rich plasma was decanted after $1 \mathrm{~h}$ at $37^{\circ} \mathrm{C}$ and centrifuged for $10 \mathrm{~min}$ at $4^{\circ} \mathrm{C}$ at $600 \mathrm{~g}$. Pelleted leukocytes were suspended in Medium 199 containing $10 \%$ autologous plasma; erythrocytes were lysed with $0.87 \%$ chilled ammonium chloride, and the leukocytes were then washed twice in Hank's balanced salt solution before final suspension in Medium 199 containing 10\% AB+ serum. Leukocytes were passed through a column $(50 \times 3 \mathrm{~cm})$ of prewarmed $\left(37^{\circ} \mathrm{C}\right)$ glass beads to eliminate polymorphonuclear leukocytes and monocytes. Viability of eluted cells was measured by trypan blue exclusion and found to exceed $90 \%$. B lymphocytes were separated from $\mathrm{T}$ lymphocytes on discontinuous gradients of bovine serum albumin and by $E$ rosetting, as previously described (2). 90-97\% of cells in the final preparation formed rosettes with EAC3 and were considered to be $B$ lymphocytes. On some occasions, the Erosetting step was omitted. This did not affect the results of IgG synthesis by the B cells.

LMF was prepared from cultures of $T$ lymphocytes with tetanus toxoid as previously described (9).

Purified B lymphocytes were suspended at a concentration of $2 \times 10^{\circ} / \mathrm{ml}$ in RPMI-1640 medium and mixed with an equal volume of LMF. After 6 days of culture at $37^{\circ} \mathrm{C}$ in air containing $5 \% \mathrm{CO}_{2}$, the $\mathrm{B}$ cells were gently centrifuged and resuspended either in Medium 199 lacking leucine, valine, and isoleucine, or in Dulbecco medium containing $1 \mu \mathrm{M}$ glucose at a leukocyte concentration of $2 \times$ $10^{\circ} / \mathrm{ml}$. Either $50 \mu \mathrm{Ci}$ of $\left[\mathrm{D}^{3} \mathrm{H}\right]$ mannose $(9 \mathrm{Ci} / \mathrm{mM})$ or 50 $\mu \mathrm{Ci}$ of $\left[\mathrm{D}-{ }^{3} \mathrm{H}\right]$ glucosamine $(10 \mathrm{Ci} / \mathrm{mM})$ was added to $1 \mathrm{ml}$ of cells in Dulbecco medium (10). In some experiments, $25 \mu \mathrm{Ci}$ of both sugars was added to a culture tube. $1 \mu \mathrm{Ci}$ of $\left[{ }^{14} \mathrm{C}\right]$ leucine $(303 \mathrm{mCi} / \mathrm{mM}), 0.5 \mu \mathrm{Ci}$ of $\left[{ }^{14} \mathrm{C}\right]$ valine $(252$ $\mathrm{mCi} / \mathrm{mM})$, and $0.5 \mu \mathrm{Ci}\left[{ }^{14} \mathrm{C}\right]$ isoleucine $(306 \mu \mathrm{mCi} / \mathrm{mM})$ were added to $1 \mathrm{ml}$ of B cells in Medium 199 (1). Cultures containing labeled sugars were incubated for $24 \mathrm{~h}$ and those containing labeled amino acids for $48 \mathrm{~h}$. After incubation, the cells were washed, resuspended to original volume, and sonicated for $30 \mathrm{~s}$ at $0^{\circ} \mathrm{C}$. The cellular debris was removed by centrifugation at $100,000 \mathrm{~g}$ for $60 \mathrm{~min}$, and the supernatant fluid was dialyzed against 900 vol of saline for $36 \mathrm{~h}$ at $4^{\circ} \mathrm{C}$.

Protein was precipitated from culture medium or cell sonicates by $10 \%$ trichloracetic acid, washed, and redissolved in $3 \%$ acetic acid. Newly synthesized IgG was precipitated from culture medium or cell sonicates with rabbit antihuman IgG which was shown to be specific by Ouchterlony analysis and inhibition of labeled IgG precipitation by cold IgG. Aggregates of newly synthesized IgG and rabbit antihuman IgG were precipitated at equivalence with goat antirabbit IgG. Control precipitations were performed with normal rabbit serum instead of rabbit antihuman IgG. Such control precipitates never exceeded $2 \%$ of the dpm in the specific precipitates (1). Immune precipitates were washed three times in $\mathrm{PBS}$ at $0^{\circ} \mathrm{C}$ and dissolved in $3 \%$ acetic acid. Radioactivity was assayed in a Packard Tri-Carb liquid scintillation apparatus. (Packard Instrument Co., Inc., Downers Grove, Ill.)

Immune precipitates were digested with pronase at $56^{\circ} \mathrm{C}$ for $48 \mathrm{~h}$. The digest was filtered through Sephadex G-25 resin (Pharmacia Fine Chemicals, Inc., Piscataway, N. J.) and the first eluate peak was concentrated by lyophilization, hydrolyzed for $2 \mathrm{~h}$ in $N$-sulfuric acid. The hydrolyzate was neutralized by ion exchange chromatography (Dowex 1HAC) and then chromatographed on Whatman No. 1 in butanol, acetic acid, pyridine, and water. (Whatman, Inc., Clifton, N. J.)

\section{RESULTS}

Normal B lymphocytes, after 6 days of exposure to LMF in culture, were found to secrete $\operatorname{IgG}$ labeled with $\left[{ }^{3} \mathrm{H}\right]$ mannose and/or $\left[{ }^{3} \mathrm{H}\right]$ glucosamine. The kinetics of secretion of the labeled IgG are shown in Fig. 1 . At $18 \mathrm{~h}$ of incubation, the maximal amount of labeled $\mathrm{IgG}$ in the culture medium was reached and it remained constant thereafter. Variable amounts of protein-bound sugar were found in the intracellular IgG during the course of the experiments.

On the basis of the kinetic experiment, the B lymphocytes of four patients with agammaglobulinemia and three control subjects were examined for protein bound and IgG-bound carbohydrate after $24 \mathrm{~h}$ of culture in the presence of $\left[{ }^{3} \mathrm{H}\right]$ mannose and/or $\left[{ }^{3} \mathrm{H}\right]$ glucosamine. There was no incorporation of sugar into newly synthesized IgG of the agammaglobulinemic patients. In normal controls, most of the bound sugar was secreted (approximately 90\%). Of the secreted proteins, 2-6\% was IgG. Carbohydrate analysis of glycopeptides isolated from the specific IgG precipitates showed that the labeled mannose and glucosamine were incorporated into newly synthesized IgG and could be recovered as mannose and glucosamine. On the other hand, less than $40 \%$ of the glycoprotein was secreted by the agammaglobulinemic B lymphocytes, none of which was IgG (Table I).

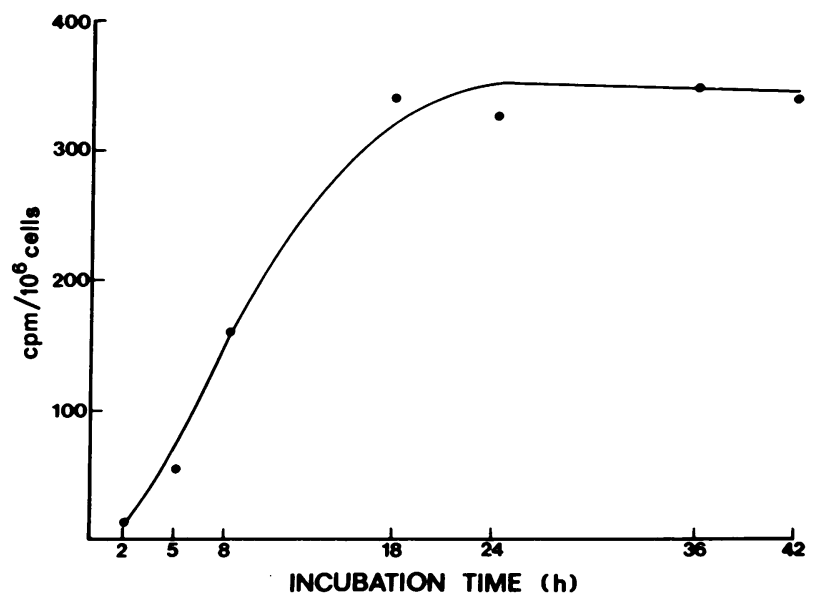

FIGURE 1 Incorporation of $\left[{ }^{3} \mathrm{H}\right]$ mannose and $\left[{ }^{3} \mathrm{H}\right]$ glucosamine into IgG synthesized de novo by human B cells obtained from peripheral blood lymphocytes of a normal individual. $\mathrm{cpm} / 10^{6}$ cells specifically precipitated by a rabbit antihuman $\mathrm{IgG}$, goat antirabbit $\mathrm{IgG}$ antiserum system as a function of time (hours). Intracellular IgG never exceeded $70 \mathrm{cpm}$. 
TABLE I

Incorporation of ${ }^{3} \mathrm{H}$-Mannose and Glucosamine and $\left[{ }^{14} \mathrm{C}\right]$ Leucine, Isoleucine, and Valine into IgG and Total Protein

\begin{tabular}{|c|c|c|c|c|c|c|c|c|}
\hline \multirow[b]{3}{*}{ Subject } & \multicolumn{4}{|c|}{ 'H-Sugars* } & \multicolumn{4}{|c|}{ "IC-Amino Acids $\ddagger$} \\
\hline & \multicolumn{2}{|c|}{ Intracellular } & \multicolumn{2}{|c|}{ Extracellular } & \multicolumn{2}{|c|}{ Intracellular } & \multicolumn{2}{|c|}{ Extracellular } \\
\hline & IgG & T.P.‡ & IgG & T.P. & IgG & T.P. & IgG & T.P. \\
\hline $18-12$ & 0 & 8,110 & $\mathbf{0}$ & 5,220 & 290 & 14,700 & $\mathbf{0}$ & 3,280 \\
\hline $23-13$ & 0 & 38,300 & 0 & 5,020 & 250 & 25,000 & 0 & 4,500 \\
\hline $13-3$ & 0 & 18,300 & 0 & 4,000 & 370 & 25,000 & 0 & 4,150 \\
\hline $23-30$ & 0 & 25,500 & 0 & 1,450 & 550 & 41,400 & 0 & 7,100 \\
\hline Control 1 & 160 & 2,200 & 890 & 19,700 & 50 & 40,500 & 450 & 7,500 \\
\hline Control 2 & 0 & 3,500 & 650 & 29,000 & 0 & 63,000 & 310 & 7,000 \\
\hline Control 3 & 0 & 1,700 & 500 & 8,300 & 0 & 50,500 & 630 & 7,900 \\
\hline
\end{tabular}

* cpm/l ml of a 2-ml culture volume.

$\ddagger$ T.P. $=$ total protein precipitable with trichloroacetic acid.

Cultures were examined for ${ }^{14} \mathrm{C}$-amino acid incorporation into protein after $48 \mathrm{~h}$. As previously reported, B cells of the four patients with agammaglobulinemia synthesized normal amounts of IgG intracellularly but failed to secrete it. Only $20 \%$ or less of newly synthesized protein was secreted by normal or agammaglobulinemic cells. In cultures of normal B lymphocytes, IgG constituted $5-8 \%$ of the total protein secreted (Table I).

The intracellular IgG from B lymphocytes of case 13-3 and extracellular fluid from a normal control was precipitated with specific antisera, and the precipitate was washed, dissolved in $1 \%$ sodium dodecyl sulfate, and reduced in $0.2 \mathrm{M}$ dithiothreitol and subjected to electrophoresis in $5 \%$ polyacrylamide gel (12). Two peaks of radioactivity were found which corresponded to the mobilities of normal $\mathrm{H}$ and $\mathrm{L}$ chains (Fig. 2). When the

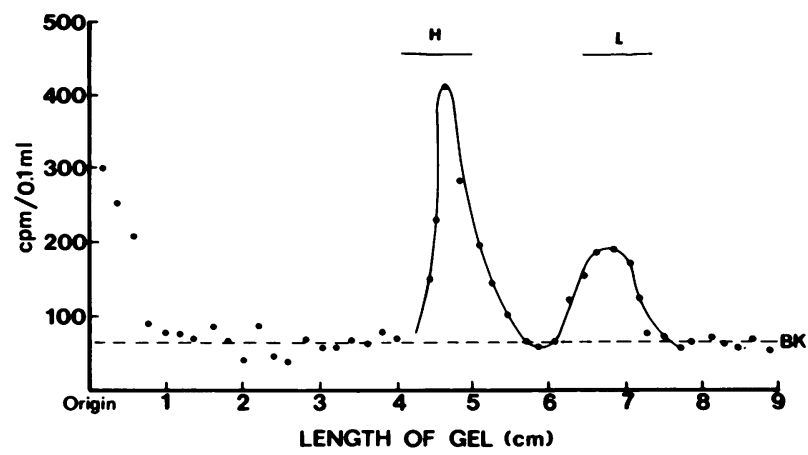

FIGURE 2 Separation by acrylamide gel electrophoresis in $0.1 \%$ SDS of the $\mathrm{L}$ and $\mathrm{H}$ chains of $\mathrm{IgG}$ synthesized de novo by $10 \mathrm{ml}$ culture of human $\mathrm{B}$ cells from a patient with common, variable agammaglobulinemia who could not secrete the newly formed protein. $\mathrm{cpm}$ of $\left[{ }^{14} \mathrm{C}\right]$ valine-isoleucine-leucine incorporated into protein specifically precipitated by a rabbit antihuman IgG, goat antirabbit IgG antiserum system as a function of distance of migration into the gel (centimeters). BK represents background counts. $\mathrm{H}$ and $\mathrm{L}$ indicate mobility of normal $\mathrm{H}$ and $\mathrm{L}$ chains. experiment was done with labeled sugars instead of labeled amino acids the label was predominantly in the $\mathrm{H}$ chains of newly synthesized IgG. Small amounts of label in the $L$ chain could not be excluded (less than $1 \%$ ).

The possibility that these lymphocytes had a faulty intracellular transport mechanism for carbohydrate was considered. In an attempt to mimic the glycosylation defect of the agammaglobulinemic cells in normal B lymphocytes, cytochalasin B (10 $\mu \mathrm{g} /$ culture $)$ was added to $B$ cell cultures $4 \mathrm{~h}$ after the start of the incubation with labeled sugars. The exposure to cytochalasin was terminated $4 \mathrm{~h}$ later, and fresh labeled sugars were added for another $18 \mathrm{~h}$ of culture. Specific precipitates were then made of newly synthesized IgG with rabbit antihuman IgG and goat antirabbit IgG. The intracellular glycosylation of $\operatorname{IgG}$ was the same in control cultures $(1,500$ $\mathrm{cpm} / 2 \times 10^{7}$ cells) as in the cytochalasin-treated cultures $\left(1,750 \mathrm{cpm} / 2 \times 10^{7}\right.$ cells $)$, whereas cytochalasin effectively inhibited secretion of the $\mathrm{IgG}$ into the extracellular fluid $\left(800 \mathrm{cpm} / 2 \times 10^{7}\right.$ cells $)$ compared with the control culture $\left(9,000 \mathrm{cpm} / 2 \times 10^{7}\right.$ cells $)$.

B lymphocytes from case 13-3 were fixed in tannic acid-glutaraldehyde and examined under a Phillips-300 electron microscope (13). Philips Electronic Instruments, Inc., Mount Vernon, N. Y. No abnormality of the microtubular structures or the microfilaments was noted.

\section{DISCUSSION}

The common, variable immunodeficiency is a syndrome of prolix clinical manifestations and probably has multiple etiologies (14). We have previously classified these patients according to the intrinsic or extrinsic abnormalities in their B lymphocytes. Some patients have no $B$ cells, whereas others have normal or increased numbers of circulating $B$ cells (5) which are unresponsive 
to a T-cell signal that, in the presence of antigen, causes $\mathrm{B}$ cells to enlarge, divide, and synthesize antibody. A third group of patients have B cells which synthesize immunoglobulin but fail to secrete the newly synthesized immunoglobulin (4). In another group of these patients, the defect appears to be extrinsic to the $B$ cells in that their normal function appears to be suppressed by factors in the blood or from suppressor $T$ cells (15). The present study is concerned with patients whose B cells synthesize but fail to secrete antibody. The secretory bloc is associated with a failure of glycosylation of the nascent gamma globulin chains, an event which occurs normally just before the secretion of immunoglobulin (8).

The patients in this study have panhypogammaglobulinemia in that their serum is grossly deficient in all the immunoglobulins. The design of the present study only elicited information concerning IgG synthesis by $\mathrm{B}$ cells. This limitation results from the fact that tetanus toxoid in the presence of LMF stimulates only IgG synthesis and secretion by normal B lymphocytes. Other antigens would have to be used to evaluate $\operatorname{Ig} M, \operatorname{IgA}$, $\operatorname{IgD}$, or $\operatorname{IgE}$ synthesis, or pokeweed mitogen might also be used for this purpose. Because the tetanus toxoid has been evaluated in detail in our laboratory, we have confined these studies to this single antigen to which the patients and the normal controls have been sensitized.

The failure of normal glycosylation of newly synthesized protein could result from any one of a number of abnormalities in the transport and activation of sugar moieties inside cells. The transport of sugar from the medium to the ribosomes is not disturbed by cytochalasin treatment of normal B cells and the microtubular structures of the abnormal B cells from the agammaglobulinemic patients appears morphologically intact in ultrastructural studies. Another possible disturbance in these $B$ lymphocytes could reside in the activation of the monosaccharide moieties by the Leloir pathway (16) or from the absence of a glycosylating enzyme in these cells. This also appears unlikely since the incorporation of labeled mannose and glucosamine into protein other than immunoglobulin proceeded in a normal fashion (Table I).

The reason for the failure of glycosylation of immunoglobulin in the $B$ cells of these agammaglobulinemic patients is not known but might be explained by an abnormality in the structure of the nascent heavy chain. The site of attachment of the sugar residues to the protein chain is well known for some of the immunoglobulins. For instance, in the IgG1 molecules, the carbohydrate is attached to an asparagine molecule at residue 297 of the heavy chain (17). In the present study, no abnormality of the heavy chains was discerned by gross examination of the newly synthesized $\mathrm{IgG}$ in polyacryl- amide gels. Further studies will be required to define any subtle abnormality in the structure of the immunoglobulin produced by these abnormal B cells, if such abnormalities are indeed present.

\section{ACKNOWLEDGMENTS}

We wish to express our gratitude to Drs. George Baker, Douglas Fearon, Emil Unanue, and Harold Amos, Mr. James Chester, and Ms. Helen Whitsed.

This paper was supported by U. S. Public Health Service grants AI-05877, AM-16392, and FR-128, and the JoAnne Paley Memorial Fund.

\section{REFERENCES}

1. Geha, R. S., E. Schneeberger, F. S. Rosen, and E. Merler. 1973. Interaction of human thymus-derived and non-thymus-derived lymphocytes in vitro. Induction of proliferation and antibody synthesis in B lymphocytes by a soluble factor released from antigen-stimulated $T$ lymphocytes. J. Exp. Med. 138: 1230-1247.

2. Geha, R. S., F. S. Rosen, and E. Merler. 1973. Identification and characterization of subpopulations of lymphocytes in human peripheral blood after fractionation on discontinuous gradients of albumin. The cellular defect in X-linked agammaglobulinemia. J. Clin. Invest. 52: $1726-1734$

3. Choi, Y. S., W. D. Biggar, and R. A. Good. 1972. Biosynthesis and secretion of immunoglobulins by peripheral blood lymphocytes in severe hypogammaglobulinaemia. Lancet. 1 : 1149-1152.

4. Geha, R. S., E. Schneeberger, E. Merler, and F. S. Rosen. 1974. Heterogeneity of "acquired" or common variable agammaglobulinemia. N. Engl. J. Med. 291: $1-6$.

5. Preudhomme, J. L., C. Griscelli, and M. Seligmann. 1973. Immunoglobulins on the surface of lymphocytes in fifty patients with primary immunodeficiency diseases. Clin. Immunol. Immunopathol. 1 : 241-256.

6. Cooper, M. D., A. R. Lawton, and D. E. Bockman. 1971. Agammaglobulinaemia with B lymphocytes. Specific defect of plasma-cell differentiation. Lancet. ii : 791794.

7. Melchers, F. 1970. Biosynthesis of the carbohydrate portion of immunoglobulins. Kinetics of synthesis and secretion of $\left[{ }^{3} \mathrm{H}\right]$ leucine-, $\left[{ }^{3} \mathrm{H}\right]$ galactose- and $\left[{ }^{3} \mathrm{H}\right]$ mannoselabelled myeloma protein by two plasma-cell tumours. Biochem. J. 119: 765-772.

8. Zagury, D., J. W. Uhr, J. D. Jamieson, and G. E. Palade. 1970. Immunoglobulin synthesis and secretion. II. Radioautographic studies of sites of addition of carbohydrate moieties and intracellular transport. J. Cell. Biol. 46: $52-63$.

9. Geha, R. S., and E. Merler. 1974. Human lymphocyte mitogenic factor: Synthesis by sensitized thymus-derived lymphocytes, dependence of expression on the presence of antigen. Cell. Immunol. 10: 86-104.

10. Della Corte, E., and R. M. E. Parkhouse. 1973. Biosynthesis of immunoglobulin A (IgA). Secretion and addition of carbohydrate to monomer and polymer forms of a mouse myeloma protein. Biochem. J. 136: 589-596.

11. Smiley, J. D., and H. Horton. 1965. Isolation and study of the function of human $\gamma_{2}$-globulin glycopeptide. Immunochemistry. 2: 61-66. 
12. Weber, K., and M. Osborn. 1969. The reliability of molecular weight determinations by dodecyl sulfatepolyacrylamide gel electrophoresis. J. Biol. Chem. 244: 4406-4412.

13. Futaesaku, Y., V. Mizuhira, and H. Nakamura. 1972. A new fixation method using tannic acid for electron microscopy and some observations of biological specimens. Proc. Int. Cong. Histochem. and Cytochem. 4: 155-156.

14. Douglas, S. D., L. S. Goldberg, and H. H. Fudenberg. 1970. Clinical, serologic, and leukocyte function studies on patients with idopathic "acquired" agammaglobulin- emia and their families. Am. J. Med. 48: 48-53.

15. Waldmann, T. A., M. Durm, S. Broder, M. Blackman, R. M. Blaese, and W. Strober. Role of suppressor T cells in pathogenesis of common variable hypogammaglobulinaemia. Lancet. ii : 609-613, 1974.

16. Leloir, L. F. 1971. Two decades of research on the biosynthesis of saccharides. Science (Wash. D. C.). 72: 1299-1303.

17. Edelman, G. M., B. A. Cunningham, W. E. Gall, P. D. Gottlieb, U. Rutishauser, and M. J. Waxdal. 1969. The covalent structure of an entire IgG immunoglobulin molecule. Proc. Natl. Acad. Sci. U. S. A. 63: 78-85. 